\title{
'Alternative' journal publishing and the economy of academic prestige
}

We are all familiar with the dire predicament that anyone aiming at pursuing an academic career currently finds oneself in, succinctly described by Lawrence Berg as apparatuses of anxiety-production in the neoliberal university (Berg et al. 2016). Within this regime of research governance, which in most places is dominated by crude quantifications of the quality of scholarly output (Jones 2017), the "gold standard" for accumulating scholarly prestige is constituted by "a small number of entirely Anglophone journals produced by the world's largest academic publishing houses" (Batterbury 2017, 176), dominated by the for-profit 'big five' academic publishing corporations. As a consequence, there is overwhelming pressure on early career scholars to publish in highly-ranked journals, which - as noted by the editorial team of Human Geography (Finn et al. 2017) - with few exceptions constitute the proprietary products of an oligopoly of large, capitalistic academic publishers.

However, even when recognizing and opposing the immensely problematic effects of current conventions of evaluating scholarly quality, it is nonetheless important to read the present predicament not only in relation to some abstract ideal state, but also in the context of a previous history. And - to be frank - academia has always been governed by an economy of prestige. As noted by Fyfe and colleagues (2017) in a recent paper on the relationship between academic prestige and scientific publishing:

"...[I]n Britain in the eighteenth and early nineteenth centuries, scholarly reputation was still closely correlated with social standing. A good scholarly reputation could be gained through membership in the appropriate societies, through meeting the right people over dinner, and by demonstrating one's knowledge through conversation or the ownership of an impressive collection of specimens or artefacts. The authorship of essays or books could feed into these social structures for generating prestige, but there are good reasons why scholarly culture in this period has been called 'gentlemanly', in reference to gender and class, as well as to the behavioural norms and social activities which were valued." (Fyfe et al. 2017, 6)

The authors further note that it is in the mid-1800s that the idea that authorship is a good way of evaluating intellectual merit begins to take root, whereby scientific learned societies increasingly came to care more about "demonstrable scholarly activity than family background" and further also began to recognize "a list of publications as a suitable entry requirement" (ibid.). By the end of the century, the publication record had become something of the standard means of demonstrating ability in competition for professorships, whereby "young researches could hope that the intangible prestige granted by the recognition of their work from others in their field might translate into an academic position“ (ibid.).

The sobering insight provided by this type of historical-institutional analysis is that long before the neoliberal era, prestige was the hard currency of the academy, and the accumulation of personal prestige has to a large extent always constituted the make or break of fledgling academic careers. However, what has changed between different times and places - and in recent decades, radically so - has been the conventions upon which such prestige has been established, and the mechanisms whereby it has been accumulated.

What perhaps particularly distinguishes the current moment is the wholesale capitalization of this economy of academic prestige, which has been facilitated through various forms of quantification that all contribute to translating the symbolic prestige of academic publishing into concrete cash-in-hand for individual academics (new positions, publication bonuses, etc.), universities (research evaluation frameworks, grants), and the whole billion-dollar global academic publishing industry dominated by a small number of for-profit enterprises, generally producing perverse profit margins.

Based on the current discussion regarding the ails of the academic publishing apparatus, conducted in this journal and in many other places, the editorial team of Fennia is working hard to continuously develop the journal into a resource for the mounting scholarly opposition to this regime by practically embodying a concrete alternative. However, we also recognize that the attractiveness of such an 
alternative is weak if it is only based on an appeal to moral sentiments. An ethical publication practice, we suggest, must also proceed from an understanding of the existing, very real and concrete academic prestige economy that any researcher, and particularly those in the early stages of their career, must painstakingly navigate.

The established routes through which early career researchers can accumulate academic prestige in the neoliberal university world are well-known: publish in highly ranked journals, pull in large grants, deliver keynote speeches at big conferences, be part of prestigious editorial boards, et cetera. The editorial collective of Fennia has neither the capacity, nor a wish to, cater to the above-mentioned established practices of prestige accumulation. But there are also more subtle ways of accumulating prestige, that do not as thoroughly contribute to feeding and reproducing the neoliberal turn of higher education. We will propose a few.

One fundamental element of generating scholarly prestige is simply to have your work read by established authorities in a research field, and to have it taken seriously as the work of an interesting up-and-coming colleague, which deserves to be noticed and commented upon. Here, journals like Fennia can have an interesting role to play as venues for generating such encounters and providing this type of prestige, as an added value for early career researchers in their consideration of where to submit their work (for detailed introduction of the following publications, see the editorial by Riding \& Kallio 2018).

Currently, the journal is developing this critical feature by means of open-open review practice. Where ethically adequate, we encourage the authors and the reviewers to engage in open conversations during the review process, facilitated by the editors. This allows, among other things, formulating revision suggestions dialogically between editors, authors and reviewers. After acceptance - the decision obviously being by the editors only - the reviewers are provided the opportunity to write a commentary, to be published alongside with the paper in Fennia. In this issue, William Walton's (2018) article with commentaries by Andy Inch (2018) and Vesa Kanninen (2018) in our Reflections section is an example of this practice.

Another dialogical publication format that we are currently experimenting is the Fennia lecture with commentaries. It works as a venue for bringing into conversation younger and older scholars, including the lecturer, participants from the Finnish Geography Days, and invited commentators from the research field in question. We began the tradition last year with Henk van Houtum's lecture (van Houtum \& Bueno Lacy 2017) with three commentaries (Hannonen 2017; Riding 2017; Scott 2017). This issue continues the annual practice with Nick Gill's (2018) essay based on the 2017 Fennia lecture, accompanied by five commentaries by Jen Bagelman (2018), Roger Norum (2018), Vilhelmiina Vainikka and Joni Vainikka (2018), Jani Vuolteenaho and Eveliina Lyytinen (2018), and Matthew Sparke (forthcoming).

The third current dialogical endeavor of the journal is the Versus forum, established in collaboration with three Finnish scientific societies (Society for Regional and Environmental Studies, Geographical Society of Finland, and Finnish Society for Environmental Social Science), and two other journals published by them (Alue \& Ympäristö, Terra). It offers the opportunity to Fennia authors to publish popularized versions of their research articles with invited commentaries from other scholars, professionals, practitioners, research participants, journalists, students, politicians, or representatives of any key audience of their research. With these Research Debates, the forum seeks to make scholarly work better accessible and known among scholars and people at large, thus we seek to identify target audiences for each piece of research to enhance academic and practical impact. First debates based on research published in Fennia will come out later this year, to be linked with the original publications, and introduced and broadly circulated by the journal.

With this editorial, we encourage scholars to invent critical forms of generating scholarly prestige, such that reach beyond the conventional practices based on unjust competition and individualizing academic culture, benefitting largely the corporate publication industry and scholars already in good positions. What can we do, from our different positions in our various scientific communities, to even up inequalities and to give value to alternative attempts in academic publishing? 
JONATHAN METZGER

FENNIA EDITORIAL BOARD MEMBER

KIRSI PAULIINA KALLIO

FENNIA EDITOR-IN-CHIEF

\section{REFERENCES}

Bagelman, J. (2018) Who hosts a politics of welcome? - commentary to Gill. Fennia 196(1) 108-110. https://doi.org/10.11143/fennia.70294

Batterbury, S. (2017) Socially just publishing: implications for geographers and their journals. Fennia 195(2) 175-181. https://doi.org/10.11143/fennia.66910

Berg, L. D., Huijbens, E. H. \& Larsen, H. G. (2016) Producing anxiety in the neoliberal university. The Canadian Geographer/Le Géographe Canadien 60(2) 168-180. https://doi.org/10.1111/cag.12261

Finn, J., Peet, R., Mollett, S. \& Lauermann, J. (2017) Reclaiming value from academic labor: commentary by the Editors of Human Geography. Fennia 195(2) 182-184. https://doi.org/10.11143/fennia.66683

Fyfe, A., Coate, K., Curry, S., Lawson, S., Moxham, N. \& Rostvik, C. M. (2017) Untangling academic publishing: a history of the relationship between commercial interests, academic prestige and the circulation of research. Zenodo [online May 25 2017] https://doi.org/10.5281/zenodo.546100

Gill, N. (2018) The suppression of welcome. Fennia 196(1) 88-98. https://dx.doi.org/10.11143/fennia.70040

Hannonen, O. (2017) Bordering the "other": the case of the Finnish-Russian border. Fennia 195(1) 113117. https://doi.org/10.11143/fennia.63674

van Houtum, H. \& Bueno Lacy, R. (2017) The political extreme as the new normal: the cases of Brexit, the French state of emergency and Dutch Islamophobia. Fennia 195(1) 85-101. https://doi.org/10.11143/fennia.64568

Inch, A. (2018) The timely return of the repressed - commentary to Walton. Fennia 196(1) 99-102. https://doi.org/10.11143/fennia.69822

Jones, M. (2017) Can research quality be measured quantitatively? On quality of scholarship, numerical research indicators and academic publishing - experiences from Norway. Fennia 195(2) 164-174. https://doi.org/10.11143/fennia.66602

Kanninen, V. (2018) Postpolitics of (Scottish) planning: gatekeepers, gatechecks and gatecrashers? commentary to Walton. Fennia 196(1) 103-107. https://doi.org/10.11143/fennia.69905

Norum, R. (2018) From welcome to well ... come: the mobilities, temporalities and geopolitics of contemporary hospitality - commentary to Gill. Fennia 196(1) 111-117. https://dx.doi.org/10.11143/fennia.70403

Riding, J. (2017) Extreme geographies: a response from a dependent semi-periphery of the postneoliberal Europe. Fennia 195(1) 106-112. https://doi.org/10.11143/fennia.59633

Riding, J. \& Kallio, K. (2018) Dialogical peer-review and non-profit open-access journal publishing: welcome to Fennia. Fennia 196(1) 4-8. https://doi.org/10.11143/fennia.70470

Scott, J. (2017) Extreme and extremist geographies: commentary on the revanchist impulse and its consequences for everyday bordering. Fennia 195(1) 102-105. https://doi.org/10.11143/fennia.63677

Sparke, M. Welcome, its suppression, and the in-between spaces of refugee sub-citizenship commentary to Gill. Fennia [online Jun 17 2018] https://doi.org/10.11143/fennia.70999

Vainikka, V. \& Vainikka, J. (2018) Welcoming the masses, entitling the stranger - commentary to Gill. Fennia 196(1) 124-130. https://doi.org/10.11143/fennia.70227

Vuolteenaho, J. \& Lyytinen, E. (2018) Reflections on the variations and spatialities of (un)welcome commentary to Gill. Fennia 196(1) 118-123. https://doi.org/10.11143/fennia.70290

Walton, W. (2018) Deregulated free-for-all planning, new settlements and the spectre of abandoned building sites in Scotland's crisis-hit oil economy. Fennia 196(1) 58-76. https://doi.org/10.11143/fennia.65626 